\title{
Analysis of Learning Styles (Kolb) in Students of the Degrees in Early Childhood Education and Primary Education within the Faculty of Education
}

\author{
Naiara Bilbao ${ }^{1}$, Arantzazu López de la Serna ${ }^{1}$, Eneko Tejada ${ }^{1}$, Ainara Romero ${ }^{1}$ \\ ${ }^{1}$ University of the Basque Country, Department of Didactics and School Organization. Barrio Sarriena, s/n, \\ 48940 Leioa, Bizkaia, Spain
}

\begin{abstract}
This research aimed to present the learning styles according to the model of Alonso, Gallego and Honey in university students of the Faculty of Education within the University of the Basque Country (Spain). With that objective, a sample of 434 students was chosen. The Honey-Alonso Learning Styles (CHAEA) questionnaire was used. The data obtained reflect that the four learning styles proposed by Kolb are distributed in a balanced way among the participating sample; they also reflect that it is not possible to attribute a specific learning style to a specific Degree, except with active learning and Early Childhood Education.
\end{abstract}

Keywords - learning styles, higher education, teaching practice, student-centered education, CHAEA questionnaire.

\section{Introduction}

Over the past few years, special interest has been placed from the field of Pedagogy in finding better

DOI: $10.18421 /$ TEM102-29

https://doi.org/10.18421/TEM102-29

Corresponding author: Naiara Bilbao, University of the Basque Country, Department of Didactics and School Organization. Barrio Sarriena, $s / n, 48940$

Leioa, Bizkaia, Spain.

Email: naiara.bilbao@ehu.eus

Received: 23 February 2021.

Revised: 04 May 2021.

Accepted: 08 May 2021.

Published: 27 May 2021.

(c) BY-NC-ND (C) 2021 Naiara Bilbao et al; published by UIKTEN. This work is licensed under the Creative Commons Attribution-NonCommercial-NoDerivs 4.0 License.

The article is published with Open Access at www.temjournal.com ways to teach, in converting the traditional teaching model into an innovative framework with the ultimate goal of deep, lasting learning. The improvement of teaching processes by teachers is undoubtedly a goal not only desirable but also necessary [1], [2], [3].

However, too much emphasis may have been placed at times on the teaching point of view and the importance of the student's perspective has not been properly recognized [4]. More specifically, the analysis of factors that influence learning such as context, socioeconomic conditions or the way students have to perceive, process and transmit the reality that surrounds them. Unlike what happens with the other variables, teachers have the ability to directly influence this last factor: the learning style.

If it seems clear that people learn differently, depending not only on their circumstances but also on their cognitive structure [5], [6], knowing the different learning styles that exist within a classroom results in valuable information for the teacher. If one is aware of that reality, one will avoid working according to a teaching-learning model in which information is always displayed and processed in the same way; thus, serving the different needs of an increasingly complex and heterogeneous student body.

Elaborating this map of learning styles is undoubtedly important in any educational context, but it is even more so if we talk about the field of Higher Education and more specifically about the training of future teachers [7]. If people who are being trained as future teachers are exposed to different ways of teaching, they can understand and internalize the importance of that reality. So that, in the future, they are themselves who put into practice a rich and varied educational approach that takes into account the diversity of the people who make up their classroom [8]. 
Therefore, the present study has been carried out to determine the different learning styles within the Degrees of Early Childhood and Primary Education belonging to the Faculty of Education in Higher Education.

\section{Literature Review}

In a broad sense, the concept of learning can be defined as the ability of the human being to perceive, process and transmit the information that surrounds it [5], [6]. To do this, tools such as observation, analysis and experience are used [9], [10], [11]. This term does not refer to the mere acquisition of information or content; on the contrary, it has to do with the processing of such information and, above all, with the ability of people to communicate, as well as their ability to create products, solve challenges, etc. [12], [13]. In addition, it is not limited to information management but the definition extends to the notion of acquiring a capacity that has the potential to modify reality as a result of an experience [14], [15], [16].

More specifically, learning styles can be defined as those cognitive, affective and physiological features that condition the degree of effectiveness with which a person responds to a specific learning context, taking into account both external and internal circumstances [17].

In recent years, the study of different learning styles has gained considerable importance [18]. It has been emphasized that there is a wide variety of ways of learning, that the environment plays a very important role in learning, that academic and personal success is largely conditioned by how each person perceives their environment [19], [20], and, finally, that there is a complex interrelationship between those who teach and those who learn [21], [22].

Throughout recent history, different models have been proposed to classify learning styles, usually based on the cognitive process that is used as a preponderant learning strategy [23], [24]. Thus, some approaches give preponderance to the acquisition of information, others to the processing of it, others to its transmission, etc.

Alice and David Kolb [25] made one of the bestknown proposals when he identified the different learning styles that a person can show. According to the author, these styles are determined by three fundamental factors: the genetic load, the vital experience and the demands of the environment [26].

Kolb argued that learning is optimal when it is the result of working information in four different phases: Act, Reflect, Theorize and Experiment. That is, through real experience a person receives certain information as a result of their interaction with the context (Acting); next, a reflexive observation about that previously lived experience takes place (Reflect); later, the reflection gives rise to an abstract conceptualization, that is, the learning that a person is able to extract from the lived experience (Theorize); finally, it goes on to active experimentation, at which time what has been learned before is put into practice [27] .

According to Kohl, each person tends to be more comfortable with one or at most two of these phases of information processing. The implications of this fact are important, since depending on how the information is presented to the students in the classroom and how they are asked to work with it (that is, in which of the 4 phases the information is presented), the process will be more or less difficult. There will be students who prefer to work from a more abstract starting point, others more theoretical, whereas others will find it more natural to start from the experience [28].

It seems important therefore to delve a little deeper into the features that constitute each of the learning styles according to David and Alice [29].

Active style refers to the people who enjoy new experiences and live with intensity the most immediate present. They like to start activities, especially if they pose a challenge. They feel less comfortable with long-term projects and planning. They prefer to work in groups and avoid adopting a passive role in the teaching-learning process.

Reflective style refers to the people who like to observe and analyze in detail before making a decision or taking the next step in their learning process. They are cautious and contemplate all possibilities before acting. They are less comfortable in situations where they have to make quick decisions and that involve little prior reflection.

Theoretical style refers to the people who prefer to work from the experience acquired, shaping wellgrounded theories from a logical point of view. They are comfortable synthesizing information and establishing causal relationships between the different elements that integrate it. They prefer to avoid situations that imply a certain level of ambiguity or that do not allow them to take a properly founded theoretical principle as a starting point.

Finally, pragmatic style refers to the people who enjoy putting into practice previously formulated ideas and theoretical approaches. One of its priorities is overcoming challenges and solving problems; for them, it is as important to do it effectively (to be able to solve the problem) as well as efficiently (doing it in the best possible way). Their learning suffers when what they are working with does not have a direct correlation with their environment, when it is difficult to apply what they have learned in their context. 


\section{Methodology}

A quantitative research has been carried out in order to determine the role of different learning styles in a sample of first-year university students belonging to Degrees in the field of Education. The research has been carried out throughout the academic year 2019-2020 and the main instrument used has been the CHAEA questionnaire.

\subsection{Objectives}

There are three objectives set with the present investigation. On the one hand, profiling the students of Early Childhood Education, Primary Education and Trilingual Model according to the four learning styles proposed by Kolb: active, reflexive, theoretical and pragmatic.

In addition, to establish if there is a relationship between the different Degrees and each of the four learning styles.

Finally, to analyze if there is a predominant learning style linked to each of the Degrees that belong to the field of Education.

\subsection{Instruments}

The CHAEA was used [16]. It consists of 80 binary items, responding with the value (1) if the participant agrees or with the value $(0)$ if he or she disagrees. In addition, four items were added at the beginning of the questionnaire, in order to analyze the participant sample based on their gender, age, degree taken and previous studies.

The questionnaire was carried out with the participants using a Google form.

Finally, the SPSS statistical program was used for data analysis. Descriptive analysis was applied as means and standard deviations. Descriptive and inferential analysis have been performed (based on ttests comparing the means of learning styles with the Degrees taken).

\subsection{Sample}

The sample consisted of first-year students from the Degrees of Early Childhood Education, Primary Education and Trilingual Model of the Faculty of Education. The Trilingual Model includes Primary Education students, but with an English level of C1.

235 students belonged to the Early Childhood Education Degree, 186 to the Primary Education Degree and 13 to the Trilingual Model, which meant a total of 434 participants. Of these, 357 were female and 76 male.

\subsection{Procedure}

The Google form with the CHAEA questionnaire was carried out with the participants on three different days, depending on the Degree to which they belonged. In all cases, it was done in a single session. Both the preparation of the questionnaire, its completion, as well as the collection of data, took place throughout the first four months of the 2019/2020 academic year.

\section{Results}

The presentation of the data obtained throughout the investigation has been organized based on three blocks of information: the distribution of the sample according to general criteria, the answers obtained from the CHAEA questionnaire and finally the results obtained when crossing the data on learning styles with the Degree taken by each participant.

\subsection{Sample Distribution}

When analyzing the data contained in the present study in relation to learning styles, it is convenient to first reflect how the sample is distributed based on general criteria such as: gender, age, Degree taken and previous studies.

Table 1 reflects the distribution of the participating sample in the present study according to gender. The data reflect that of the sample on which the different learning styles were evaluated, the majority belonged to the female gender $(82.3 \%)$ versus a more minority representation of the male gender $(17.5 \%)$.

Table 1. Sample data organized according to GENDER

\begin{tabular}{|c|c|c|c|c|c|}
\hline & & 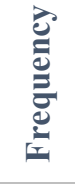 & 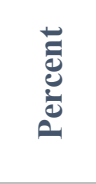 & 吾 & 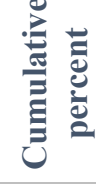 \\
\hline \multirow{3}{*}{ Valid } & Male & 76 & 17.5 & 17.6 & 17.6 \\
\hline & Female & 357 & 82.3 & 82.4 & 100.0 \\
\hline & Total & 433 & 99.8 & 100,0 & \\
\hline Missing & System & 1 & .2 & & \\
\hline TOTAL & & 434 & 100.0 & & \\
\hline
\end{tabular}

Table 2 details the distribution of the sample but this time depending on the age. As reflected in the table, a significant majority of participants belonged to the age range between 17 and $18(75.1 \%)$, but the rest $(24.9 \%)$ belonged to the age range between 19 and 29. 
Table 2. Sample data organized according to AGE

\begin{tabular}{|c|c|c|c|c|c|}
\hline & & 预 & 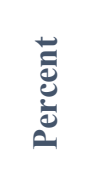 & 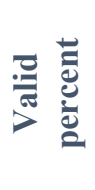 & $\underset{\Xi}{\stackrel{\Xi}{\Xi}}$ \\
\hline \multirow{10}{*}{ 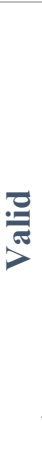 } & 17 & 56 & 12.9 & 12.9 & 12.9 \\
\hline & 18 & 270 & 62.2 & 62.2 & 75.1 \\
\hline & 19 & 28 & 6.5 & 6.5 & 81.6 \\
\hline & 20 & 36 & 8.3 & 8.3 & 89.9 \\
\hline & 21 & 24 & 5.5 & 5.5 & 95.4 \\
\hline & 22 & 6 & 1.4 & 1.4 & 96.8 \\
\hline & 23 & 6 & 1.4 & 1.4 & 98.2 \\
\hline & 25 & 6 & 1.4 & 1.4 & 99.5 \\
\hline & 29 & 2 & .5 & .5 & $\begin{array}{c}100 . \\
0\end{array}$ \\
\hline & TOTAL & 434 & 100.0 & 100.0 & \\
\hline
\end{tabular}

Table 3 reflects the distribution of the sample according to the Degree taken by each participant. There is a fairly balanced distribution between Primary Education and Early Childhood Education (42.9\% and $54.1 \%$ respectively), representing the Trilingual Model only $3 \%$ of the total sample.

Table 3. Sample data organized according to CURRENT DEGREE

\begin{tabular}{|c|c|c|c|c|c|}
\hline & & 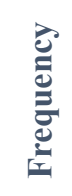 & $\begin{array}{l}\stackrel{\Xi}{0} \\
\stackrel{0}{0} \\
0\end{array}$ & 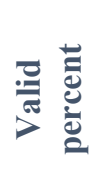 & 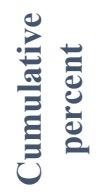 \\
\hline \multirow{4}{*}{$\frac{\pi}{\frac{\pi}{\pi}}$} & Primary & 186 & 42.9 & 42.9 & 42.9 \\
\hline & Early Childhood & 235 & 54.1 & 54.1 & 97.0 \\
\hline & Trilingual model & 13 & 3.0 & 3.0 & 100.0 \\
\hline & TOTAL & 434 & 100.0 & 100.0 & \\
\hline
\end{tabular}

Table 4 reflects the level of studies prior to the completion of the Degree by the participants in the present study. A large majority (84.6\%) of them had finished Baccalaureate, representing other degrees only $15.5 \%$ of the total sample.

Table 4. Sample data organized according to PREVIOUS STUDIES

\begin{tabular}{|c|c|c|c|c|c|}
\hline & & 窇 & 䒕 & 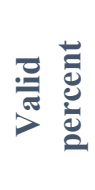 & $\underset{\circlearrowright}{\stackrel{\Xi}{\Xi}}$ \\
\hline \multirow{4}{*}{$\begin{array}{l}\frac{\sigma}{\pi} \\
\frac{\pi}{\pi}\end{array}$} & Baccalaureate & 367 & 84.6 & 84.6 & 84.6 \\
\hline & $\begin{array}{l}\text { Vocational } \\
\text { training }\end{array}$ & 65 & 15.0 & 15.0 & 99.5 \\
\hline & Other degrees & 2 & .5 & .5 & 100.0 \\
\hline & TOTAL & 434 & 100.0 & 100.0 & \\
\hline
\end{tabular}

Finally, Table 5 reflects the distribution of the sample, but in this case crossing the results obtained based on 2 variables: gender and current Degree. The data reflect a significant preference of female participants for the Degree in Early Childhood Education, although, in the case of male participants, it occurs in the opposite way, showing a clear preference for the Degree of Primary Education.

Table 5. Sample data organized across the GENDER and the CURRENT DEGREE

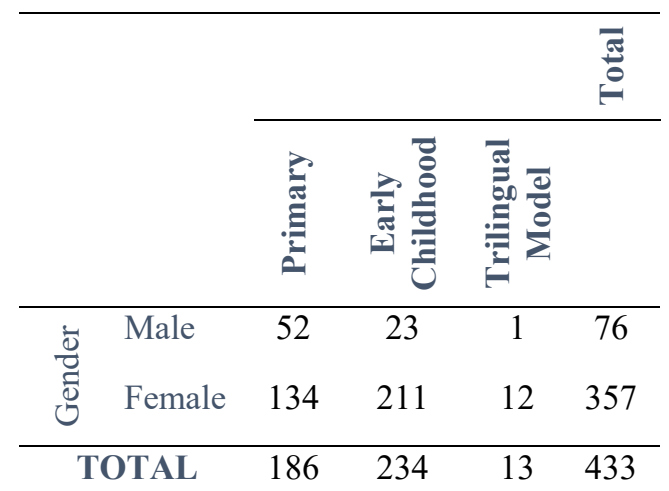

\subsection{Results of the Honey-Alonso survey}

Once the distribution of the sample has been established based on the criteria already mentioned, the results obtained in the CHAEA are reflected below. The scale used to interpret these results is shown in Table 6 below.

Table 6. Scale to interpret the results obtained in the Honey-Alonso Questionnaire on Learning Styles (CHAEA)

\begin{tabular}{|c|c|c|c|c|c|}
\hline & 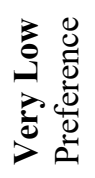 & 总 & 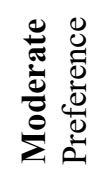 & 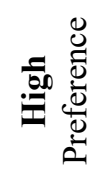 & 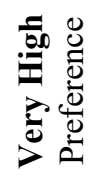 \\
\hline Active & $0-6$ & $7-8$ & $9-12$ & $13-14$ & $15-20$ \\
\hline Reflective & $0-6$ & $11-13$ & $14-17$ & $18-19$ & 20 \\
\hline Theoretical & $0-6$ & $7-9$ & $10-13$ & $14-15$ & $16-20$ \\
\hline Pragmatic & $0-6$ & $9-10$ & $11-13$ & $14-15$ & $16-20$ \\
\hline
\end{tabular}

In general, and as reflected in Table 7, the average of the four learning styles is in a zone of Moderate preference, but sometimes very close to the zone of High preference. If analyzed by learning styles, it can be seen that the average active learning style is 12.87 (with a deviation of 2.98), which places it at the gates of the High preference zone. In the case of the reflexive style, the average is 15.94 (with a deviation of 2.44), that is, in the middle zone of the Moderate preference range. The average theoretical learning style is 13.38 (with a deviation of 2.58), again very close to the High preference range. Finally, the pragmatic learning style reflects an average of 12.92 (with a deviation of 2.43), a value also very close to the High preference zone. 
Table 7. Results obtained in the Honey Alonso Questionnaire on Learning Styles (CHAEA)

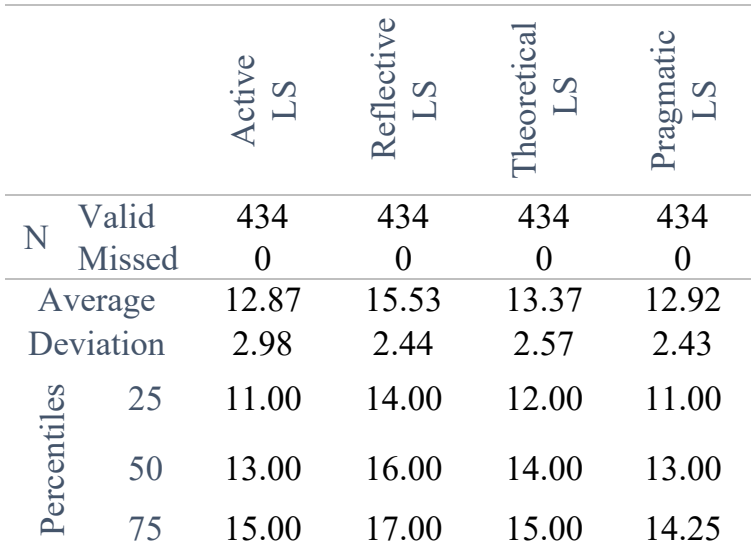

Next, the results obtained by the questionnaire in relation to each of the learning styles are reflected in more detail. Table 8 shows the degree of incidence of active learning style according to the questionnaire. In comparative terms, the Very Low and Low preferences have an insignificant incidence. On the contrary, the Moderate and Very High preferences represent the largest group of participants, although the High preference also yields remarkable results, since it makes up almost a quarter of the total sample $(24 \%)$.

Table 8. Results obtained ACTIVE Learning Styles

\begin{tabular}{lccc}
\hline & & Frequency & Percent \\
\hline Very low pref. & $0-6$ & 10 & 2.4 \\
Low pref. & $7-8$ & 38 & 8.7 \\
Moderate pref. & $9-12$ & 138 & 31.8 \\
High pref. & $13-14$ & 104 & 23.9 \\
Very high pref. & $15-20$ & 144 & 33.2 \\
\cline { 2 - 4 } & Total & 434 & 100.0
\end{tabular}

Table 9 shows the degree of incidence of reflective learning style according to the questionnaire. On this occasion, and unlike the previous case, more than half of the results are located in the Moderate preference zone $(58 \%)$, with the High and Low preference zones being the following in terms of number of results. The Very Low or Very High preference zones represent a very low percentage with respect to the total, since they do not reach $6 \%$.

Table 9. Results obtained REFLECTIVE Learning Styles

\begin{tabular}{lccc}
\hline & & Frequency & Percent \\
\hline Very low pref. & $0-10$ & 12 & 2.9 \\
Low pref. & $11-13$ & 66 & 15.2 \\
Moderate pref. & $14-17$ & 252 & 58 \\
High pref. & $18-19$ & 92 & 21.2 \\
Very high pref. & 20 & 12 & 2.8 \\
\cline { 2 - 4 } & Total & 434 & 100.0
\end{tabular}

Table 10 shows the degree of incidence of the theoretical learning style according to the questionnaire. As with the active style, a significant percentage of the results $(35.4 \%)$ focus on the Moderate preference zone. However, this time it is the High preference zone that has the highest number of responses $(36.4 \%)$, followed at some distance by the Very High preference zone (19.4\%). As in all previous cases, the lowest incidence of responses is located in the Very Low preference zone.

Table 10. Results obtained THEORETICAL Learning Styles

\begin{tabular}{lccc}
\hline & & Frequency & Percent \\
\hline Very low pref. & $0-6$ & 6 & 1.5 \\
Low pref. & $7-9$ & 32 & 7.4 \\
Moderate pref. & $10-13$ & 154 & 35.4 \\
High pref. & $14-15$ & 158 & 36.4 \\
Very high pref. & $16-20$ & 84 & 19.4 \\
\cline { 2 - 4 } & Total & 434 & 100.0
\end{tabular}

Finally, Table 11 shows the degree of incidence of the pragmatic learning style according to the questionnaire. As in the previous case, the highest number of responses is given in the areas of preference Moderate and High, although it is the first that registers the highest percentage by a large margin (43.4\% vs. $25.4 \%)$. Once again, and as with the other learning styles, the Very Low preference zone represents the lowest percentage of responses.

Table 11. Results obtained PRAGMATIC Learning Styles

\begin{tabular}{lccc}
\hline & & Frequency & Percent \\
\hline Very low pref. & $0-8$ & 16 & 3.8 \\
Low pref. & $9-10$ & 54 & 12.5 \\
Moderate pref. & $11-13$ & 188 & 43.4 \\
High pref. & $14-15$ & 110 & 25.4 \\
Very high pref. & $16-20$ & 66 & 15.3 \\
\cline { 2 - 4 } & Total & 434 & 100.0
\end{tabular}

\subsection{Learning Styles in each Degree}

Next, the data obtained through the questionnaire of learning styles according to the Degrees are reflected, with the objective of reflecting whether there is a learning style that can be clearly associated with a specific Degree.

As Table 12 reflects, there is a clearly higher incidence of active learning in the sample belonging to Early Childhood Education, $30.02 \%$ compared to $15.05 \%$ of the sample belonging to Primary Education in the High preference zone. However, even if this difference is maintained, it is markedly reduced if we take into account the Very High preference zone: $34.47 \%$ versus $32.25 \%$. As for the Trilingual Model, $100 \%$ of the participants are located from the Moderate preference zone. 
Table 12. ACTIVE learning style and CURRENT DEGREE

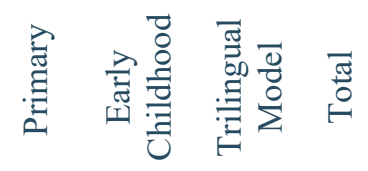

\begin{tabular}{lccccc}
\hline Very low pref. & $0-6$ & 4 & 6 & 0 & 10 \\
Low pref. & $7-8$ & 22 & 16 & 0 & 38 \\
Moderate pref. & $9-12$ & 72 & 61 & 5 & 138 \\
High pref. & $13-14$ & 28 & 71 & 5 & 104 \\
Very high pref. & $15-20$ & 60 & 81 & 3 & 144 \\
\cline { 2 - 6 } & Total & 186 & 235 & 13 & 434
\end{tabular}

Table 13 shows that if the reflective learning style is analyzed, the results, although by a narrow margin, are reversed: $59.14 \%$ of the participants in the sample belonging to Primary Education are located in the area of Moderate preference, but this only occurs with $56.17 \%$ in the case of Early Childhood Education. As for the Trilingual Model, in this case $100 \%$ of the participants are located in the Low and Moderate preference zones.

Table 13. REFLECTIVE learning style and CURRENT DEGREE

$$
\text { 坣 离总 }
$$

\begin{tabular}{lccccc}
\hline Very low pref. & $0-10$ & 6 & 6 & 0 & 12 \\
Low pref. & $11-13$ & 18 & 45 & 3 & 66 \\
Moderate pref. & $14-17$ & 110 & 132 & 10 & 252 \\
High pref. & $18-19$ & 46 & 46 & 0 & 92 \\
Very high pref. & 20 & 6 & 6 & 0 & 12 \\
\cline { 2 - 6 } & Total & 186 & 235 & 13 & 434
\end{tabular}

Table 14 shows that there are hardly any significant differences between the Degrees of Early Childhood Education and Primary Education in terms of the incidence of theoretical learning style. In both the Moderate and High preference zones and in the Very High preference zone, the variations are barely significant: $35.32 \%$ and $19.35 \%$ in the case of Early Childhood Education and $36.56 \%$ and $20.43 \%$ in the case of Primary Education respectively. On this occasion, the Trilingual Model shows more distributed results among the different areas of preference, with most of them (53.85\%) being located in the zone of High preference.
Table 14. THEORETICAL learning style and CURRENT

\begin{tabular}{|c|c|c|c|c|c|}
\hline & & $\stackrel{\vec{E}}{\Xi}$ & 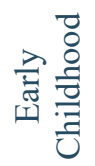 & 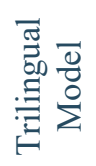 & 吾 \\
\hline Very low pref. & $0-6$ & 0 & 5 & 1 & 6 \\
\hline Low pref. & $7-9$ & 14 & 16 & 2 & 32 \\
\hline Moderate pref. & $10-13$ & 68 & 83 & 3 & 154 \\
\hline High pref. & $14-15$ & 68 & 83 & 7 & 158 \\
\hline \multirow[t]{2}{*}{ Very high pref. } & $16-20$ & 36 & 48 & 0 & 844 \\
\hline & Total & 186 & 235 & 13 & 434 \\
\hline
\end{tabular}
DEGREE

Finally, Table 15 reflects the degree of incidence of the pragmatic learning style in the three Degrees, the results being in this case of a mixed nature: although there is a greater incidence in Early Childhood Education in the High Preference zone (26,38\% vs. $23.66 \%)$, it is the areas of Moderate and Very High preference which acquire greater prominence in the case of Primary Education (42.55\% vs. $46.24 \%$ and $14.02 \%$ vs. $17.20 \%$ respectively). As for the Trilingual Model, there is no area of preference that predominates clearly over others.

Table 15. PRAGMATIC learning style and CURRENT DEGREE

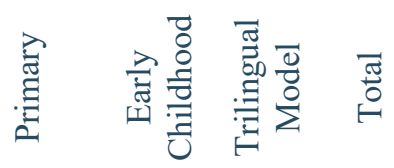

\begin{tabular}{lccccc}
\hline Very low pref. & $0-8$ & 6 & 7 & 3 & 16 \\
Low pref. & $9-10$ & 18 & 33 & 3 & 54 \\
Moderate pref. & $11-13$ & 86 & 100 & 2 & 188 \\
High pref. & $14-15$ & 44 & 62 & 4 & 110 \\
Very high pref. & $16-20$ & 32 & 33 & 1 & 66 \\
\cline { 2 - 6 } & Total & 186 & 235 & 13 & 434
\end{tabular}

\section{Discussion and Conclusion}

The objectives of the present investigation were to know the learning styles according to the model of Alonso et al. [16] in a sample of students of Early Childhood Education, Primary Education and Trilingual Model, in addition to trying to determine if there is a correlation between the Degrees and each learning style and if it is possible to establish a predominant learning style based on said Degrees. 
The learning styles reflected through the CHAEA questionnaire show fairly balanced results, the reflective learning style being the only one that does not approach the High preference zone; both the active, theoretical and pragmatic style are placed halfway between the high zone of Moderate preference and the lower zone of High preference.

Thus, the results are in line with the proposal of various authors [29], [30], [31], who insist on the importance of teachers knowing about the existence and traits of all learning styles and teaching according to them. That is, offering their students a wide range of approaches and perspectives that can satisfy the learning peculiarities of all students.

The fact that different learning styles occur within a classroom results in the richness of the teachinglearning process [32], [33]. It has to therefore be seen as an opportunity and not as an obstacle to reach educational excellence. In this context, the teacher who is able to alternate between the different styles will have a greater capacity to reach each and every one of his students. It is therefore necessary that a particular teacher does not concentrate his daily professional performance around a single style.

Regarding the possible relationship between a specific learning style and a specific Degree, there have been no significant differences that allow clear conclusions to be drawn about it. Even if it is true that the Degree in Early Childhood Education reflects a greater incidence of active learning style, this only occurs in a certain area of preference. This difference is significantly reduced if we take into account other areas of preference. A possible explanation for this could be the more dynamic, flexible, active nature of that school stage, characteristics similar to those of said learning style. In all other styles, the differences are even less significant.

As a future line, it seems advisable to look for the possible correlation between a specific learning style and academic success [34], [35], [36]. That is, trying to establish whether a trend in academic results can be anticipated based on a particular style.

Another possible line of research would be to find out if there is a correlation between the learning styles and the socioeconomic level of the sample, to try to understand how a student's environment influences his way of learning [37], [38].

It would also be advisable to expand the sample in several ways. On the one hand, expand the study to samples of students of Degrees who do not have a direct relationship with Education. On the other hand, the study could also be provided with a longitudinal character, in order to analyze whether the preponderance of one learning style or another remains unchanged over time or, on the contrary, it evolves.

\section{References}

[1]. Aubert Simon, A., Flecha Fernandez, A., García Yeste, C., Flecha García, R., \& Racionero Plaza, S. (2011). Aprendizaje dialógico en la sociedad de la información. Barcelona: Hipatia.

[2]. Flecha, R. (2009). Cambio, inclusión y calidad en las comunidades de aprendizaje. Cultura $y$ educación, 21(2), 157-169. https://doi.org/10.1174/113564009788345835

[3]. González, A. G., \& Díez-Palomar, J. (2009). Metodología comunicativa crítica: transformaciones y cambios en el S. XXI. Teoría de la Educación. Educación y Cultura en la Sociedad de la Información, 10(3), 103-118.

[4]. Stone Wiske, M. (1999). La enseñanza para la comprensión. Vinculación entre la investigación y la práctica. Editorial Paidós. Buenos Aires.

[5]. Gardner, H. (2016). Estructuras de la mente: la teoría de las inteligencias múltiples. Fondo de cultura económica.

[6]. Gardner, H. (2001). La inteligencia reformulada: las inteligencias múltiples en el siglo XXI (No. 159.955 G171i Ej. 1 020338). Paidos,.

[7]. Negre, J. S., Trobat, M. F. O., \& Forgas, R. L. C. (2016). Medidas para la mejora de la formación inicial de los maestros según el profesorado de un departamento de pedagogía. Bordón. Revista de pedagogía, 68(2), 155-168. https://doi.org/10.13042/Bordon.2016.68210

[8]. Perkins, D. (2008). Smart schools: From training memories to educating minds. Simon and Schuster.

[9]. Biggs, J. B. (1993). From theory to practice: A cognitive systems approach. Higher education research and development, 12(1), 73-85. https://doi.org/ 10.1080/0729436930120107

[10]. Ocaña, J. (2010). Mapas mentales y estilos de aprendizaje. España: Ed. Club Universitario.

[11]. Pashler, H., McDaniel, M., Rohrer, D., \& Bjork, R. (2008). Learning styles: Concepts and evidence. Psychological science in the public interest, 9(3), 105-119.

https://doi.org/10.1111/j.1539-6053.2009.01038.x

[12]. Perkins, D., \& Chua, F. (2012). Learning that matters: An expanding universe. Retrieved from: http://www.pz.harvard.edu/resources/learning-thatmatters-an-expanding-universe [accessed: 10 January 2021].

[13]. Pogré, P., \& Lombardi, G. (2004). Escuelas Que Ensenan a Pensar/Schools That Show How to Think: Ensenanza Para La Comprension. Un Marco Teorico Para La Accion/teaching To Understand/a Theoretically Mark For Action. Papers editores.

[14]. Un aula para pensar: aprender y enseñar

[15]. Wilson, D., \& Ortega.,(2013). Learning That Matters. Retrieved from: https://bityl.co/41XI [accessed: 15 January 2021].

[16]. Alonso, C. M., Gallego, D. J., \& Honey, P. (1997). Los estilos de aprendizaje: procedimientos de diagnóstico y mejora. Bilbao, España: Mensajero. 
[17]. James, W. B., \& Gardner, D. L. (1995). Learning styles: Implications for distance learning. New Directions for Adult and Continuing Education, 1995(67), 19-31. https://doi.org/10.1002/ace.36719956705

[18]. Haggart, W. (2011). Discipline and learning styles: an educator's guide. Worthy Shorts Inc.

[19]. Reid, G. (2005). Learning styles and inclusion. Sage.

[20]. Rosenberg, M. (2013). Spotlight on learning styles. Peaslake: Delta Publishing, 123-133.

[21]. Tuan, L. T. (2011). Matching and Stretching Learners' Learning Styles. Journal of Language Teaching \& Research, 2(2). https://doi.org/10.4304/JLTR.2.2.285-294

[22]. Esteves, M. Z., \& Correa, L. F. (2008). Identificación de los estilos de aprendizaje en estudiantes universitarios. Revista de estilos de aprendizaje, 1(2)

[23]. Pierart, C. G. A., \& Pavés, F. R. (2011). Estilos de aprendizaje, género y rendimiento académico. Revista de estilos de aprendizaje, 4(8).

[24]. Ruiz Ospino, E. A., \& Sánchez Fontalvo, I. M. (2019). Qué piensan los profesores universitarios de los estilos de aprendizaje. Editorial Unimagdalena.

[25]. Kolb, A. Y., \& Kolb, D. A. (2005). Learning styles and learning spaces: Enhancing experiential learning in higher education. Academy of management learning \& education, 4(2), 193-212. https://doi.org/10.5465/AMLE.2005.17268566

[26]. Kolb, A. Y., \& Kolb, D. A. (2009). The learning way: Meta-cognitive aspects of experiential learning. Simulation \& gaming, 40(3), 297-327. https://doi.org/10.1177/1046878108325713

[27]. Peterson, K., \& Kolb, D. A. (2017). How you learn is how you live: Using nine ways of learning to transform your life. Berrett-Koehler Publishers.

[28]. Kolb, D. A. (2007). The Kolb learning style inventory. Boston, MA: Hay Resources Direct.
[29]. Montealegre, G., \& Nunez, M. L. (2009). ¿ Tienen aprendizajes de calidad los estudiantes de medicina?. Acta Médica Colombiana, 34(3), 122-127.

[30]. Morin, E. (1999). Los siete saberes necesarios para la educación del futuro. Retrieved from: https://bityl.co/4WmF [accessed: 05 February 2021].

[31]. Vélez van Meerbeke, A., \& Roa González, C. N. (2005). Factores asociados al rendimiento académico en estudiantes de medicina. Educación médica, 8(2), 24-32.

https://doi.org/10.4321/S1575-18132005000200005

[32]. Trigwell, K. (2002). Approaches to teaching design subjects: a quantitative analysis. Art, Design \& Communication in Higher Education, 1(2), 69-80. https://doi.org/ 10.1386/adch.1.2.69

[33]. Trigwell, K., Prosser, M., \& Taylor, P. (1994). Qualitative differences in approaches to teaching first year university science. Higher education, 27(1), 7584. $\quad$ https://doi.org/ 10.1007/BF01383761

[34]. Manrique, C. R. C., Villavicencio, L. M., Figueroa, D. M. R., \& Puente, R. T. (2008). Estudio descriptivo de los estilos de aprendizaje de docentes universitarios. Revista de Estilos de Aprendizaje, 1(1).

[35]. Pérez, G. E., \& Ospina, P. G. (2010). Estilos de aprendizaje y rendimiento académico en estudiantes de Psicología. Diversitas, 6(1), 97-109. https://doi.org/10.15332/s1794-9998.2010.0001.07

[36]. Saúl, J. L. C., \& Guadalupe, H. C. S. (2011). Rendimiento académico y estilos de aprendizaje en estudiantes de psicología. Revista de Estilos de aprendizaje, 4(7).

[37]. Lee, R., Hoe Looi, K., Faulkner, M., \& Neale, L. (2020). The moderating influence of environment factors in an extended community of inquiry model of e-learning. Asia Pacific Journal of Education, 1-15. https://doi.org/10.1080/02188791.2020.1758032

[38]. Mirrahimi, S., Tawil, N. M., Abdullah, N. A. G., Surat, M., \& Usman, I. M. S. (2011). Developing conducive sustainable outdoor learning: The impact of natural environment on learning, social and emotional intelligence. Procedia Engineering, 20, 389-396. https://doi.org/10.1016/j.proeng.2011.11.181 